
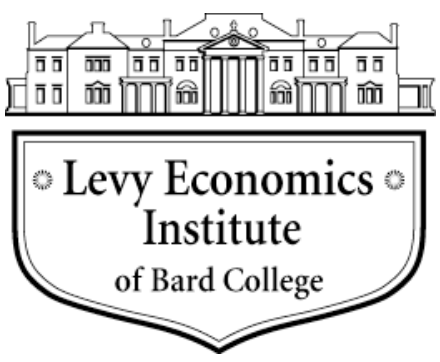

Working Paper No. 729

\title{
Veblen's Institutionalist Elaboration of Rent Theory
}

by

\author{
Michael Hudson \\ Levy Economics Institute of Bard College
}

August 2012

The Levy Economics Institute Working Paper Collection presents research in progress by Levy Institute scholars and conference participants. The purpose of the series is to disseminate ideas to and elicit comments from academics and professionals.

Levy Economics Institute of Bard College, founded in 1986, is a nonprofit, nonpartisan, independently funded research organization devoted to public service. Through scholarship and economic research it generates viable, effective public policy responses to important economic problems that profoundly affect the quality of life in the United States and abroad.

Levy Economics Institute P.O. Box 5000 Annandale-on-Hudson, NY 12504-5000

http://www.levyinstitute.org

Copyright (C Levy Economics Institute 2012 All rights reserved

ISSN 1547-366X 


\begin{abstract}
As the heirs to classical political economy and the German historical school, the American institutionalists retained rent theory and its corollary idea of unearned income. More than any other institutionalist, Thorstein Veblen emphasized the dynamics of banks financing real estate speculation and Wall Street maneuvering to organize monopolies and trusts. Yet despite the popularity of his writings with the reading public, his contribution has remained isolated from the academic mainstream, and he did not leave behind a "school."

Veblen criticized academic economists for having fallen subject to "trained incapacity" as a result of being turned into factotums to defend rentier interests. Business schools were painting an unrealistic happy-face picture of the economy, teaching financial techniques but leaving out of account the need to reform the economy’s practices and institutions.

In emphasizing how financial "predation” was hijacking the economy’s technological potential, Veblen's vision was as materialist and culturally broad as that of the Marxists, and as dismissive of the status quo. Technological innovation was reducing costs but breeding monopolies as the finance, insurance, and real estate (FIRE) sectors joined forces to create a financial symbiosis cemented by political-insider dealings-and a trivialization of economic theory as it seeks to avoid dealing with society’s failure to achieve its technological potential. The fruits of rising productivity were used to finance robber barons who had no better use of their wealth than to reduce great artworks to the status of ownership trophies and achieve leisure-class status by funding business schools and colleges to promote a self-congratulatory but deceptive portrayal of their wealth-grabbing behavior.
\end{abstract}

Keywords: History of Economic Thought; Institutionalism; FIRE Sector; Financialization JEL Classifications: B15, G02 


\section{INTRODUCTION}

Simon Patten recalled in 1912 that his generation of American economists-most of whom studied in Germany in the 1870s — were taught that John Stuart Mill's 1848 Principles of Political Economy was the high-water mark of classical thought. However, Mill's reformist philosophy turned out to be "not a goal but a half-way house” toward the Progressive Era's reforms. Mill was "a thinker becoming a socialist without seeing what the change really meant,” Patten concluded. “The Nineteenth Century epoch ends not with the theories of Mill but with the more logical systems of Karl Marx and Henry George” (Patten [1912] 1924). ${ }^{1}$ But the classical approach to political economy continued to evolve, above all through Thorstein Veblen.

Like Marx and George, Veblen’s ideas threatened what he called the "vested interests.” What made his analysis so disturbing was what he retained from the past. Classical political economy had used the labor theory of value to isolate the elements of price that had no counterpart in necessary costs of production. Economic rent-the excess of price over this "real cost"-is unearned income. It is an overhead charge for access to land, minerals or other natural resources, bank credit, or other basic needs that are monopolized.

This concept of unearned income as an unnecessary element of price led Veblen to focus on what now is called financial engineering, speculation, and debt leveraging. The perception that a rising proportion of income and wealth is an unearned "free lunch" formed the take-off point for Veblen to put real estate and financial scheming at the center of his analysis at a time when mainstream economists were dropping these areas of concern.

Veblen's exclusion from today's curriculum is part of the reaction against classical political economy’s program of social reform. By the time he began to publish in the 1890s, academic economics was in the throes of a counter-revolution sponsored by large landholders, bankers, and monopolists denying that there was any such thing as unearned income. ${ }^{2}$ The new post-classical mainstream accepted existing property rights and privileges as a "given.” In contrast to Veblen’s argument that the economy was all about organizing predatory schemes, this approach culminated in Milton Friedman’s Chicago School defense, the pro-rentier argument: "There is no such thing as a free lunch."

\footnotetext{
${ }^{1}$ See, also, Patten (1899, p. 339).

${ }^{2}$ On the tendency of post-classical economics to reject the idea of unearned income, see Patten (1891). I discuss this doctrinal shift in Hudson (2011).
} 
This blunt denial rejected the preceding three centuries of classical value and price theory, along with its policy conclusions promoting taxation of land and other natural endowments, and financial reform. Dropped from view was rentier overhead in the form of predatory and unproductive forms of wealth seeking. The post-classical mainstream treats all income as "earned," including that of rentiers. Lacking the classical concepts of unproductive labor, credit or investment, today's textbooks describe income as a reward for one's contribution to production, and wealth as being “saved up” as a result of someone's productive investment effort, not as an unearned or predatory free lunch.

This shift in theory has shaped the seemingly empirical National Income and Product Accounts to indulge in a circular reasoning that treats recipients of rent and interest as providing a service, an economic contribution equal to whatever rentiers receive as “earnings.” There are no categories for unearned income or speculative asset-price gains.

Veblen described the largest sectors of the economy where quick fortunes were made as being all about organizing rent-seeking opportunities to obtain income without real cost. He viewed psychological utility as social in character. In contrast to food or other satiable bodily needs characterized by diminishing marginal utility-e.g., from eating food and becoming satiated-his concept of conspicuous consumption emphasized the insatiable drives to raise one's social status.

The desire for consumer goods was characterized by fads for the priciest goods as trophies of one's wealth. The result was mercenary vulgarity. Wealthy Babbitts turning culture into an arena for shifting fashion to impress others. The largest factor defining status was the neighborhood where one's home was located. Housing was not simply a basic living space “use value.” It established one’s position in society, duly enhanced by civic boosterism, public subsidy, and infrastructure spending.

To deal with these issues and preserve the critique of rentier income, speculation and insider dealing, Veblen helped lead economics into the new discipline of sociology.

\section{THE CENTRAL ROLE OF REAL ESTATE}

As the economy's largest asset, real estate was the great popular arena in which to seek speculative gains. Nowhere was this more visible than in small towns, which Veblen found to have had "a greater part than any other in shaping public sentiment and giving character to 
American culture” (Veblen 1923, p. 142ff.). The country town was basically a project to puff up real estate prices.

Its name may be Spoon River or Gopher Prairie, or it may be Emporia or Centralia or Columbia. The pattern is substantially the same, and is repeated several thousand times with a faithful perfection which argues that there is no help for it ...

The location of any given town has commonly been determined by collusion between 'interested parties' with a view to speculation in real estate, and it continues through its life-history (hitherto) to be managed as a real estate "proposition.” Its municipal affairs, its civic pride, its community interest, converge upon its real-estate values, which are invariably of a speculative character, and which all its loyal citizens are intent on "booming" and "boosting," - that is to say, lifting still farther off the level of actual ground-values as measured by the uses to which the ground is turned. Seldom do the current (speculative) values of the town's real estate exceed the use-value of it by less than 100 per cent.; and never do they exceed the actual values by less than 200 per cent., as shown by the estimates of the tax assessor; nor do the loyal citizens ever cease their endeavours to lift the speculative values to something still farther out of touch with the material facts. A country town which does not answer to these specifications is "a dead one," one that has failed to "make good," and need not be counted with, except as a warning to the unwary "boomer." (Ibid.)

Describing real estate as being "the great American game," Veblen focused on how future prices were enhanced over present values by advertising and promotion. "Real estate is an enterprise in 'futures,' designed to get something for nothing from the unwary, of whom it is believed by experienced persons that 'there is one born every minute."” Farmers and other rural families from the surrounding lands look “forward to the time when the community's advancing needs will enable them to realise on the inflated values of their real estate,” that is, find a sucker "to take them at their word and become their debtors in the amount which they say their real estate is worth.” The entire operation, from individual properties to the town as a whole, is “an enterprise in salesmanship,” with collusion being the rule. ${ }^{3}$

Retailers in small towns collude to exploit farmers, a practice broken by the spread of mail order catalogues. But monopoly power is achieved most rigorously in local banking. Most loans are for mortgages to inflate land prices. “And the banker is under the necessity_- 'inner necessity,' as the Hegelians say — of getting all he can and securing himself against all risk, at the

\footnotetext{
${ }^{3}$ Other contemporaries described how the great American real estate fortunes were obtained by fraud and insider dealing. Myers (1907) focused on John Jacob Astor in New York and the land that Trinity Church vestrymen gave themselves, and how Leland Stanford and his California gang in Congress obtained land grants for their railroads. Frank Norris's 1901 novel The Octopus described the railroads' exploitation of California.
} 
cost of any whom it may concern, by such charges and stipulations as will insure his net gain in any event.”

Land prices were rising in larger cities as a result of overall prosperity and the easier availability of mortgage financing, while public spending on roads, subway and bus systems, parks, museums, and other prestigious activities were organized to enhance neighborhood values. $^{4}$

\section{VEBLEN'S CONTEXT IN THE AMERICAN SCHOOL OF POLITICAL ECONOMY AND INSTITUTIONALISM}

Veblen wrote in the tradition of the self-described American School of economists. Focusing on technology and the rising productivity of labor and energy-driven capital, its members developed an alternative to Ricardian doctrine. ${ }^{5}$ Describing diminishing returns and British class antagonisms as a special case, they focused on increasing returns as the universal wave of the future. I attribute the failure of most historians of economic thought to relate Veblen to this school (or even to acknowledge its existence) to its protectionist policy conclusions.

Liberal historians such as Joseph Dorfman have dismissed this school for describing the United States as an “exception” to the British rule. But the opposite is more accurate. Patten accused British political economy of assuming universal validity for peculiarly British institutions and practices, above all by identifying wages, rent, and profits with particular social classes, advocating universal free trade and assuming that all public spending was overhead (as in war spending), not capital investment in infrastructure. The result was that Britain was behind the times, holding on to an intolerantly "monist” (one size fits all) outlook. Patten urged an “economic pluralism” that followed the German historical school—which became known as institutionalism in the United States - in recognizing that economies were organized in a wide variety of ways. (Patten [1912] 1924, p. 278f.)

From Patten to Veblen, critics of rentiers were so diverse that it would be misleading to refer to them as a "school” as such. Their common denominator was a focus on unearned income and exploitation, which required government policy to reform. Their analytic scope encompassed social institutions, legal and tax systems, educational and public policy

\footnotetext{
${ }^{4}$ Fitch (1996) analyzed how real estate elites planned the gentrification of New York City's real estate over the $20^{\text {th }}$ century. Today, the value of New York City real estate exceeds the book value of all the plant and equipment in the United States.

${ }^{5}$ I discuss this School's contribution in Hudson (2010), which includes a review of how Dorfman misrepresented and misunderstood it.
} 
priorities headed by subsidies and tariffs. The result was a more complex and also more empirical view than that which characterized the individualistic, abstract, and indeed simplistic marginal utility school that was replacing classical political economy from the 1870s onward.

Nowhere was this more the case than in land rent, natural resource rent, and monopoly rent. Ricardo described land rent as stemming from diminishing returns widening the margin between high-cost producers (who set the price of food) and low-cost landowners who received the economic rent from rising crop prices. The American School cited progress in chemical fertilizers, mechanized farm production, and the development of transport infrastructure as increasing productivity in agriculture as well as industry. Instead of fertility being "original and indestructible” as Ricardo claimed, soil chemistry and capital investment in farm equipment and public support services were turning land into capital, yielding returns in the form of profit.

The Ricardian-Malthusian “Iron Law of Wages” used a simplistic supply-and-demand analysis to imply that population growth and chronic unemployment would keep wages near subsistence levels. American economists developed an Economy of High Wages theory to explain the nation's rising wage levels. Instead of attributing high wages to the "backwoods" availability of free land, Henry Carey pointed out that unless labor was sufficiently productive to sustain higher output, industry could not afford to pay high wages. He attributed the nation's wage levels to technological progress requiring highly skilled labor to operate highproductivity capital. The result was a universal theory of progress, becoming global as higherpaid labor undersold pauper labor — thus forcing laggard countries to join the wave of progress.

Patten's idea that technology was transforming economies from a "pain" to a "pleasure" society led naturally to Veblen’s idea of an “instinct of workmanship.” Machines were taking over many of the drudgery tasks, freeing human labor for higher, more intellectually absorbing work. Patten and Veblen anticipated Schumpeter in viewing rent as super-profit created by the increasing returns resulting from the advance of science and technology. ${ }^{6}$ Lowering costs created opportunities for innovators to earn what Alfred Marshall termed quasi-rents—rewards

\footnotetext{
${ }^{6}$ Patten (1902, p. 139f.): "Rent is constantly being created by social progress, but in any particular form it is steadily being cut down by the increase in the power of substitution" as businessmen developed substitutes for monopolized goods and services.
} 
for innovation in contrast to income raked off by idle rentiers. Gutenberg's innovation of movable type to print the Bible and other books, for example, enabled him to sell them at the same price as competitors using more costly hand copying and engraving systems.

This line of analysis prompted Veblen to describe increasing returns as leading to the monopolies being organized by Wall Street. It was in this financial arena that progress became untracked by monopoly rent used for financial speculation and trust building.

Marshall's generation treated current production and consumption as the "real" economy. Despite the transformative role that finance has played, subsequent mainstream economists treat markets as if most money is paid for goods and services, not real estate, bonds, stocks, or other assets. Money and prices appear only as a veil, as “counters.” Price changes are viewed merely as replacing pounds with kilograms (or pounds sterling with dollars). Production and consumption constitute the "real" economy, while money and pricesand debt-are only a means of circulating goods and services, not as imposing a debt overhead. Debt is a matter of choice - to consume in the present rather than later, or to invest to make a profit, not as unnecessary "watered costs" or unproductive loans or debts.

Yet all money and credit is debt, after all—and debt determines who gets what, and how income is distributed or siphoned off. By excluding this line of analysis, the mainstream approach diverts attention from the financial speculation and debt overhead on which Veblen focused.

\section{ELABORATING THE CONCEPT OF ECONOMIC RENT TO FOCUS ON UNEARNED FORTUNES}

Writing two decades before Veblen, the journalist Henry George obtained a popular following by denouncing landlords and urging taxation of the land's full rental value. But lacking grounding in classical value and rent theory, he was unable to express his ideas in formal economic terms, and adamantly opposed extending the concept of economic rent to the banking sector. And George soon turned to attacking socialists and other Progressive Era campaigners for promoting reforms other than his Single Tax panacea. Nonetheless, his campaigning inspired fear among landlords, bankers and other rentiers that the concept of economic rent would be used to limit their gains. Veblen (along with Patten) fought a rear-guard effort against the new mainstream. While George's followers retained a Ricardian focus on agricultural land, he emphasized financial speculation, recognizing that land rent was being capitalized into mortgages and paid to bankers. 
Veblen described how credit was being created for speculative reasons rather than to finance the production of goods and services. Pre-Ricardian political economy had focused on debt and interest (especially James Steuart, Malachy Postlethwayt, and Adam Smith). But postclassical economists turned their attention away from the monetary and financial dimension of life, which Veblen termed "pecuniary.” Mainstream economics strips away these embedded characteristics.

Denial of the classical distinction between value and price (and hence, between earned and unearned income) was led by John Bates Clark in the United States, and by a similar "pragmatic" tradition in European supply and demand analysis. From Veblen's perspective this attempt at "universals” trivialized economics. Criticizing business schools for teaching how to make money by creating extractive financial tollbooths without increasing society's productive powers, he found rentier interests behind the narrow-mindedness that ignored the predatory character of rent and interest. The emerging “individualistic” orthodoxy had a pro-rentier bias, endorsing practices that bled the productive economic core to support a neo-rentier class.

To recognize charges over and above the economy’s necessary engineering costs, analysis must take into account institutional factors - especially financial dynamics and other rentier overhead. There are many ways to embed a given mode of production, and some are freer of rentier charges than others. Soviet Russia, America, Japan, Britain, and Germany shared a similar technological repertory of power production, automotives, air transport, and computer science in the 1970s and 1980s, yet had different property and banking systems and price regulation for public infrastructure and other monopolies. Land rent, mineral rent, financial returns, and monopoly pricing are country-specific and time-specific, and hence find little role in models seeking to depict economics as an abstract natural science on universal principles like physics and chemistry.

By placing rent in its financial context and political setting, Veblen became part of the sociology discipline, consigned to the basement of the social sciences to exclude from the core curriculum discussion about tax reform and other checks or regulation concerning how economic rent was obtained by ownership rights and privileges, monopolies and political corruption. 


\section{THE RENTIERS SEEK TO LIMIT THE SCOPE OF ECONOMIC ANALYSIS TO MAKE THEMSELVES INVISIBLE}

The post-classical school accused its institutionalist critics and social reformers of being “anti-theoretical.” Geoffrey Hodgson opens his Evolution of Institutional Economics by citing representative statements from mainstream economists claiming that institutionalism is more descriptive than analytic, succumbing to a plethora of facts and therefore belonging more to the sphere of sociology than economics. Ronald Coase's complaint that institutionalism “was 'not theoretical but anti-theoretical' has been repeated uncountably by others ..."7

The empirical trend among the American School of protectionist economists had a long pedigree going back to Daniel Raymond and Friedrich List (in the time he spent in Pennsylvania in association with Mathew Carey). ${ }^{8}$ In 1848, Calvin Colton (a protectionist economic writer close to Henry Clay) wrote that economic generalities applicable to Britain and other European nations were "entirely inapplicable” to the United States. The differences in economic and social structure between the United States and Britain had not "been duly weighed as an element of public economy.” Rather than the precepts of British political economy being universal in scope, "public economy has never been reduced to a science, and ... all the propositions of which it is composed, down to this time, are empirical laws” (Colton 1848, pp. 18, 46, and 38).

Economics thus finds little objective universally agreed-upon principles to analyze the costs and benefits of protective tariffs, industrial subsidies or privatized versus public ownership or operation. Models of economic rent and the political context for economic policy are ideological. This opens up discussion of progressive alternatives to British free trade economics and political assumptions rationalizing the status quo as equilibrium.

Taking the lead in developing new general laws for how industry was becoming financialized, Veblen countered the post-classical conflation of rent and interest with profits (“earnings”) on three major grounds:

\footnotetext{
${ }^{7}$ Hodgson (2004, p. 3), citing Coase (1984, p. 230) and Langlois (1986, p.5): “The problem with the Historical School and many of the early Institutionalists is that they wanted an economics ... without theory."

${ }^{8}$ In his Outlines of American Political Economy (1827), Friedrich List wrote: “American national economy, according to the different conditions of the nations, is quite different from English national economy.” I discuss this early period of institutionalism in Hudson (1975, pp. 45-54 and 115-32).
} 
(1) The timeless and decontextualized generalities drawn by the pro-rentier logic used circular reasoning to justify the status quo as being natural and in equilibrium. By definition, there was no rentier exploitation, even as economies were polarizing. Assuming that every income recipient is paid for a contribution to production implies that the existing distribution of property and mode of financing are optimum. There thus seems to be no need for reform or regulation, either socialist or protectionist.

(2) It is not a virtue for post-classical economics to be value-free. Denying the concept of economic rent as the excess of market price over cost value leads to a conflation of land with capital, rent with interest. Land is treated as a "factor of production," not a monopoly right independent of production, a privilege to put an economic tollbooth in place to extract rent.

(3) Excluding the political dimension of classical political economy is implicitly laissez faire. It leaves no role for government - the only power able to regulate and tax land rent and prevent the financial sector from turning itself into an oligarchy. "Free market" opposition to government regulation blocks reforms aimed at bringing prices in line with costs so as to make economies more efficient. “One-size-fits all” generalities lead to Margaret Thatcher's intolerant and censorial assertion: "There is no alternative.”

In sum, over-simplicity in excluding discussion of the rentiers' free lunch achieves a higher level of abstraction by ruling out concepts that would deem rentier income to be unearned and hence unnecessary. All such revenue-economic rent-is "institutional” in the sense that it is not based on the universals of technological costs of production or abstract “supply and demand.” Institutions, especially banking and tax systems, are not universal but are historically determined.

Focusing on status quo costs burdened with heavy rentier charges implies that an input is worth whatever the buyer pays for it. In practice, this means whatever a bank will lend against its collateral value or income stream. This depends on the terms on which loans are made and regulated. Taking the prices of land or monopoly "tollbooth" rent-extracting rights as “givens” means accepting whatever investors must lay out as a valid cost, including payments for rent-extracting privileges or bank credit created with little inherent production cost. Rentier privileges are capitalized without regard to necessary labor cost on which classical economists focused in isolating the "free lunch" element of price not reducible to labor. 
Housing and land ownership were more widely distributed in the United States than in Europe, largely on credit as banking entered into a symbiosis with real estate and other rentextracting activities. Mortgage credit often absorbs the entire land rent. Financing charges are built into the acquisition price of property or rentier rights, but are not intrinsic to production and have no counterpart in an engineering view of the economy. Wall Street insiders refined the practice of simply issuing bonds to themselves (“watered stock”). These unnecessary “false costs of production," were factored into the cost of operating railroads and industrial trusts.

Such practices prompted Veblen to criticize Clark and also Marshall for ignoring the “pecuniary” financial dimension of life. This was a glaring error of omission in the new mainstream, along with monopolies and large real estate frauds started in colonial times, highlighted by the Yahoo land fraud early in the Republic, and capped by the railroad land grants. As Henry C. K. Liu describes how Veblen emphasized the predatory role of high finance:

Veblen put forth a basic distinction between the productiveness of "industry" run by skilled engineers, which manufactures real goods of utility, and the parasitism of "business," which exists only to make profits for a leisure class which engages in "conspicuous consumption." The only economic contribution by the leisure class is "economic waste," activities that contribute negatively to productivity. By implication, Veblen saw the US economy as being made inefficient and corrupt by men of "business" who deviously put themselves in an indispensable position in society. (Liu 2011)

\section{CHANGING EVALUATIONS OF VEBLEN IN ACADEMIA-DORFMAN AND HIS CRITICS}

“If the eye offend thee, pluck it out”-or at least, distract attention from Veblen's line of analysis that opened the path for thinking about how institutions might be changed. Rather than dealing with Veblen's ideas that offended the post-classical mainstream, his critics ignored those with which they disagreed, and shifted attention to his striking personality. It is an old rhetorical trick of lawyers: character assassination of unfriendly witnesses. As Aldous Huxley quipped in Brave New World: "Great is truth, but still greater, from a practical point of view, is silence about truth. By simply not mentioning certain subjects ... totalitarian propagandists have 
influenced opinion much more effectively than they could have by the most eloquent denunciations.”

Columbia University professor Joseph Dorfman’s long-standard biography of Veblen made him non-threatening by taking his ideas out of their $19^{\text {th }}$-century political context that focused on land, finance, and monopolies with a view to minimize rentier charges. Rejecting this intellectual context on ideological grounds, Dorfman wrote an anecdotal soap opera that found favor with Columbia's Economics Department's prevailing pro-rentier ideology.

The department had always been free trade and pro-British. As the early center for opposition to Henry George's land-tax advocacy — and hence to the analysis of land rent as unearned income-most professors found Veblen's analysis of land speculation anathema. Dorfman's dissertation advisor was Wesley Mitchell. Trained by Veblen, his lectures on Types of Economic Theory provide a good fair-minded treatment. But he was on leave out of the United States most of the year when Dorfman was writing his book. ${ }^{9}$ The result sanitized Veblen from a perspective typical of his Columbia colleagues, airbrushing out Veblen's focus on rentiers. Dorfman did the same thing with his five-volume overview of American economic thought, censoring the protectionist and technology mainstream that dominated US policy and political debates throughout the $19^{\text {th }}$ century. On balance, he was the kind of academic whom Veblen’s Higher Education in America skewered for being so narrow-minded. ${ }^{10}$

The past decade has seen a reaction against Dorfman's treatment of Veblen. The $4^{\text {th }}$ Conference of the International Thorstein Veblen Association, held at The New School on May 12, 2002, was highlighted by Steven Edgell's paper on "Dorfman's Account of Veblen.” Russell and Sylvia Bartley’s biographical study of “Veblen’s Formal Education at Carleton College 1874-1880” also criticized Dorfman's treatment of Veblen. (Alas, these proceedings were not published.) Their point was that Veblen was in the majority in his own context. Although America is not very Norwegian, Minnesota certainly was. The Bartleys characterize him as a "folk savant," a common phenomenon in Norwegian communities—a brilliant exception to the conformist norm. This role would have provided Veblen with self-confidence to take on the establishment. It certainly helps to be an outsider to recognize dysfunctional

\footnotetext{
${ }^{9}$ Dorfman published his study of Veblen before submitting it as a dissertation, which explains why the dissertation did not cite page numbers or other references — not even the title of Veblen's own doctoral dissertation at Yale (which was stolen from the library the following year). Columbia dutifully applauded, awarding Dorfman the Seligman Prize for distinguished scholarship in 1935.

${ }^{10}$ My own impression on meeting Dorfman on a number of occasions was that he was somewhat like how he described Veblen: outsiderish.
} 
social dynamics, economic hypocrisy, and egotism - and to see that what most people accept as natural will have to be changed if the economy is to be made more fair, lower-cost, and hence more competitive. 


\section{VEBLEN'S DISPARAGING VIEW OF THE BUSINESS MENTALITY AND ACADEMIA}

Veblen criticized academic economists for having fallen subject to "trained incapacity" as a result of being turned into factotums to defend rentier interests. Business schools were painting an unrealistic happy-face picture of the economy, teaching financial techniques but leaving out of account the need to reform the economy's practices and institutions.

In a conclusion recalling Veblen's Higher Education in America, Herman Kahn describes how peer pressure leads experts to accept explanations that deviate from accepted concepts:

Educated incapacity often refers to an acquired or learned inability to understand or even perceive a problem, much less a solution. The original phrase, "trained incapacity," comes from the economist Thorstein Veblen, who used it to refer, among other things, to the inability of those with engineering or sociology training to understand certain issues which they would have been able to understand if they had not had this training. (Kahn 1979, pp. 482-484)

Kahn adds that this phenomenon occurs especially "at leading universities in the United States-particularly in the departments of psychology, sociology, and history, and to a degree in the humanities generally. Individuals raised in this milieu often have difficulty with relatively simple degrees of reality testing." The problem is greatest in economics, of course.

\section{NON-INDUSTRIAL CHARACTER OF TODAY'S FINANCIAL CRISIS}

Today’s bank privileges and the financial sector's rise to dominance are a survival of these precapitalist conquests and royal war debts that took root in Europe’s Crusades. From antiquity to the sacking of Byzantium in 1204, the characteristic mode of financial accumulation was to loot the temples and palaces where societies stored their savings, and extract taxes as tribute from conquered populations. Military conquest evolved into the levy of land rent, while creditors used their gains to purchase monopoly privileges.

Industrial capitalism was more productive, although just as cruel in creating an urban labor force by driving cultivators off the land and forcing them to work for wages to live. This exploitation of wage labor at least employed workers, and took a great step forward by accumulating capital as part of the production process. In due course, employers found that increasing labor productivity (so as to create more surplus value) requires raising wages and living standards to provide higher education, better health and diets—and at a point, more 
leisure. So despite the aim of cutting costs to undersell competitors, technological innovation was accompanied by high-wage labor underselling pauper labor. That is why American manufacturers undersold their British counterparts—not only because of higher labor productivity, but because of the thriving domestic market as labor rose into the middle class.

This was done by a combination of government sponsorship and largely productive credit, including lending for home ownership. Mixed economies were out-competing those lacking strong public sectors to subsidize industry, sponsor rising productivity and prevent landlords, bankers, and monopolists from imposing heavy rentier charges. By the turn of the $20^{\text {th }}$ century, it seemed that the destiny of industrial capitalism was to evolve into socialism. Pensions, health care, roads and basic infrastructure, public education-all were coming to be provided outside of "the market.” Industrial capital backed this policy as a means of shifting as many "external" costs as possible onto the public sector.

Writing earlier than Veblen, Marx was more optimistic that the imperatives of industrial capitalism would industrialize banking to fund industrial production. Nobody of his period expected the financial sector to mount a counter-revolution against the Progressive Era's reforms. From Ricardo to Henry George, Marx noted, industrialists had an innate hatred of land rent. Their aim was to obtain the economic surplus for industry, not leave it in the hands of a landed aristocracy. And the interest of banks seemed to lie with industry, not real estate.

Along with mineral rights and basic infrastructure, natural monopolies were expected to become part of the public sector, including the bankers' privilege of creating credit and charging interest with no corresponding cost of production. Followers of Saint-Simon hoped that banks would finance capital investment more by equity participation than by interestbearing debt. The economic program of enlightened industrial capitalism was to tax away rent and develop basic infrastructure, including banking, as a public utility and provide its services at cost or at subsidized rates (e.g., free roads rather than toll roads). This seemed to be the road along which industrial nations were moving in the years leading up to World War I. Economic democracy promised to liberate society from the hereditary land ownership, privatization of natural resources, and monopoly privileges surviving from feudal epochs.

But the war deflected the path of Western civilization. Taxes on land, natural resources, and the financial sector have been unwound. Labor is exploited fiscally by a regressive income tax (the early US income tax fell only on the well-to-do at its inception in 1913, not on wage 
earners), and by sales taxes on consumption such as Europe's Value Added Tax (VAT) as taxes are shifted off property. Property has been democratized —on tax-deductible credit while its price gains are taxed at lower rates than wages and profits, if at all. The $1 \%$ have managed to fight back and drive the bottom 99\% into debt, headed by mortgage debt and a tax shift off property and financial wealth. Instead of industrial investment and public spending spurring expansion, finance capital's strategy is to find borrowers to purchase rent-extracting tollbooth opportunities.

The end result is austerity, as business as well as governments become deeply indebted. Debt pressures are leading governments to privatize public services, enabling a new class of debt-leveraged rentiers to make their gains by inflating the cost of living and doing business.

It wasn't supposed to be this way. Bank debts are not the result of prior savings emerging from the dynamic of industrial capitalism. Modern bank credit is created on computer keyboards. Unlike industry employing labor to, this electronic credit has almost no cost of production. It is empty "price without value" as defined by the classical economists, and is extractive rather than productive. It is lent against collateral already in place, not to create new means of production.

Aimed at reversing the Progressive Era’s reforms, today’s neoliberal (that is, anticlassical) counter-reforms have over-layered the industrial exploitation of wage labor, by finance capitalism indebting it via mortgage loans, student loans, auto loans, credit card overdrafts, and other bank debt. Labor is exploited as saver as well as debtor, with its pension fund set-asides turned over to financial managers. The pretense is that this turns labor into capitalists-in-miniature. But the dynamic is part of finance capitalism, not industrial capitalism. Instead of investing directly in means of production or giving pension contributors the voice in management that true ownership does, pension savings are lent out to indebt the industrial economy. Hedge funds and corporate raiders borrow to downsize companies, and outsource and offshore employment.

The result is a race to the bottom in terms of working conditions and living standards. Instead of making economies more competitive, austerity shrinks markets and leads to loan defaults, foreclosures - and emigration. The resulting crisis is being used as an opportunity to force yet more privatization of the public domain —on tax-subsidized credit. Neither Marx nor Veblen imagined that capitalism would take so self-destructive a path. 


\section{FROM MARX TO VEBLEN}

Early (and most non-Marxist) socialism aimed to achieve greater equality mainly by taxing away unearned rentier income and keeping natural resources and monopolies in the public domain. The Marxist focus on class conflict between industrial employers and workers relegated criticism of rentiers to a secondary position, leaving that fight to more bourgeois reformers. Financial savings were treated as an accumulation of industrial profits, not as the autonomous phenomenon that Marx himself emphasized in Volume 3 of Capital.

Headed by Lenin, Marx’s followers discussed finance capital mainly in reference to the drives of imperialism. The ruin of Persia and Egypt was notorious, and creditors installed collectors in the customs houses in Europe’s former Latin American colonies. The major problem anticipated was war spurred by commercial rivalries as the world was being carved up.

It was left to Veblen to deal with the rentiers' increasingly dominant yet corrosive role, extracting their wealth by imposing overhead charges on the rest of society. The campaign for land taxation and even financial reform faded from popular discussion as socialists and other reformers became increasingly Marxist and focused on the industrial exploitation of labor.

Home ownership was rising in the cities, on credit, and commercial investors mounted a campaign to persuade homeowners that cutting property taxes would benefit them as well as absentee owners. But what the tax collector relinquished became available to be pledged as interest to the banks. Mortgage debt soared as property taxes were cut - to a point where most rental value is now capitalized into mortgage loans and paid to the banks.

The Single Taxers slipped off the right wing of the political spectrum as they failed to link their campaign to see that bankers were the major contenders against landlords and the government to end up with the land rent, by capitalizing it into bank loans. They followed Henry George in becoming libertarian anti-government and anti-socialist ideologues-a selfcontradictory political stance, because government was the only power strong enough to tax and regulate land and monopolies, and counter the banking lobby. Veblen accordingly poked fun at the Single Taxers as ineffective idealists and out-of-touch sectarians (Veblen [1904] 1965, pp. 351-52fn.; Veblen [1906] 1919, p. 337).

Veblen described how the rentier classes were on the ascendant rather than being reformed, taxed out of existence, or socialized. His Theory of Business Enterprise (1904) 
emphasized the divergence among productive capacity, the book value of business assets, and their stock-market price (what today is called the Q ratio of market price to book value). He saw the rising financial overhead as leading toward corporate bankruptcy and liquidation. Industry was becoming financialized, putting financial gains ahead of production. Today’s financial managers use profits not to invest but to buy up their company's stock (thus raising the value of their stock options) and pay out as dividends, and even borrow to pay themselves. Hedge funds have become notorious for stripping assets and loading companies down with debt, leaving bankrupt shells in their wake in what George Akerlof and Paul Romer have characterized as looting. ${ }^{11}$

After a wave of financial speculation and corporate fraud led the dot.com stock market bubble to burst in 2000, banks nurtured an even larger and more burdensome real estate bubble. Indebting the economy has enabled the financial sector to absorb most of the revenues squeezed out by the insurance and real estate sectors, along with the major monopolies (minerals, fuels and power, radio and television, telephones and transport) and privatized infrastructure sold off from the public domain to become rent-extracting opportunities. On top of the landlords — and now over industry—stand the bankers, lording it over them and using debt leverage to take control of governments as well. Yet neither socialist critiques nor those of mainstream economic futurists have focused on the financial takeover of society and its symbiosis with real estate and monopolies to which Veblen pointed. By the 1960s, theorists of the post-industrial "service economy" were focusing on information technology, not on the financial sector.

In emphasizing how financial "predation” was hijacking the economy’s technological potential, Veblen's vision was as materialist and culturally broad as that of Marxists, and as rejecting of the status quo. Technological innovation was reducing costs but breeding monopolies as the Finance, Insurance and Real Estate (FIRE) sectors joined forces to create a financial symbiosis cemented by political insider dealings - and a trivialization of economic theory as it seeks to avoid dealing with society’s failure to achieve its technological potential. The fruits of rising productivity were used to finance robber barons who had no better use of their wealth than to reduce great artworks to the status of ownership trophies and achieve

\footnotetext{
${ }^{11}$ See Akerlof and Romer (1993). This article is thoroughly in Veblen's tradition.
} 
leisure class status by funding business schools and colleges to promote a self-congratulatory but deceptive portrayal of their wealth-grabbing behavior.

Yet Veblen was as optimistic as Marx when it came to the prospects for industrial capitalism to uplift society. Whereas Marx expected it to subordinate banking and finance to promote industrial objectives - and for revolution to be led from below, by the working class (or its political party representatives) — Veblen anticipated that a managerial class of industrial engineers might lead the world toward a more rational, socially functional economy. As Ahmet Öncü observes in his remarks to the Istanbul 2012 Veblen conference:

In his chapter "A Memorandum on a Practicable Soviet of Technicians” published in The Engineers and the Price System [1921], Veblen talks about a possible future scenario. According to Veblen, capitalists will give up, albeit reluctantly, the ownership of industries not by force but by their own choice. Veblen offers this reasoning: "It should, in effect, cause no surprise to find that they will, in a sense, eliminate themselves, by letting go quite involuntarily after the industrial situation gets quite beyond their control.” (Öncü 2012)

But contrary to Veblen’s expectation, industry has been financialized, and planning has been centralized in Wall Street, the City of London, the Paris Bourse, and Frankfurt, rather than in public hands or those of industrial engineers. Stock and bond markets, and even the mortgage market have been turned into arenas for gambling, with debt leveraging being the new means of appropriating property, using junk bonds as the weapon of choice. Opportunities for rent extraction and for capital gains that are taxed at only half the rate of profits, if at all. The upshot of this “economic game,” as Veblen put it, is not capital investment in new plant and equipment to produce profits by employing labor, but speculative “capital” gains in asset prices-an exercise in promotion and collusion not unlike his country town example on a more gigantic financial scale.

Industrial engineers have been superseded by financial engineers as economic planners. MIT started as an engineering institution, but ended up with Paul Samuelson and other anti-classical writers teaching that economics was purely abstract and deductiveprecisely what Veblen attacked. Virginia Tech founded a College of Business in 1961 and used the term "rent-seeking activity” to describe public activity (e.g., James Buchanan at the ideological Center for Public Choice), not for private-sector rentiers.

The financial sector is unwilling to relinquish its hold simply because the economy is shrinking. Its dynamic is now crashing in a wave of debt deflation, imposing economic 
austerity and unemployment. Debts are going bad, and foreclosure time has arrived. But instead of restructuring the economy to free it for renewed progress, the financial class sees today's crisis as an opportunity for a property grab to vest itself as a new elite to rule the $21^{\text {st }}$ century.

It would be a mistake to view today’s finance capitalism as the "final stage" of industrial capitalism. The name of the new game is neofeudalism and austerity, and its preferred mode of exploitation is debt peonage. Like creditors in ancient Rome, today's financial power is seeking to replace democracy with a financial oligarchy. The result is a resurgence of pre-capitalist “primitive accumulation,” by debt creation and foreclosure rather than the military conquests of past epochs.

\section{CONCLUSION}

As the heirs to classical political economy and the German historical school, the American institutionalists retained rent theory and its corollary idea of unearned income. More than any other institutionalist, Veblen emphasized the dynamics of banks financing real estate speculation and Wall Street maneuvering to organize monopolies and trusts. Yet despite the popularity of his writings with the reading public, his contribution has remained isolated from the academic mainstream, and he did not leave a "school." The rentier strategy has been to make rent extraction invisible, not the center of attention it occupied in classical political economy. One barely sees today a quantification of the degree to which overhead charges for rent, insurance and interest are rising above the cost of production, even as this prices financialized economies out of world markets.

The narrowing of Chicago-style monetarism and neoliberalism has left the economics discipline in much the state that Max Planck applied to physics from Maxwell to Einstein: Progress occurs one funeral at a time. The old conservatives die off, freeing the way for more progressive successors to take the steering wheel. But what makes today's economics different is that it actually would help to look backward, to the epoch before the financial sector and its allied rentier interests hijacked the discipline. The most systematic analysis of this process was that of Veblen nearly a century ago. It remains sufficiently relevant that Marxists and more heterodox critics have incorporated his theorizing into their worldview. 


\section{REFERENCES}

Akerlof, George and Paul Romer. 1993. "Looting: The Economic Underworld of Bankruptcy for Profit.” Brookings Papers on Economic Activity 1993(2): 1-73, also published as NBER Working Paper No. R1869 (April 1994).

Bartley, Russell H. and Sylvia Erickson Bartley. 2000. "Stigmatizing Thorstein Veblen: A Study in the Confection of Academic Reputations.” International Journal of Politics, Culture, and Society 14(2): 363-400.

—. 2002. "The Formal Education of Thorstein Veblen: His Carleton Years, 1874-1880.” Paper presented at the $4^{\text {th }}$ Conference of the International Thorstein Veblen Association, May 12, 2002 (unpublished).

Coase, Ronald. 1984. “The New Institutional Economics.” Journal of Institutional and Theoretical Economics 140: 229-231.

Colton, Calvin. 1848. Public Economy for the United States. New York: A. S. Barnes \& Co.

Dorfman, Joseph. 1946-1959. The Economic Mind in American Civilization (5 vols.). New York: Augustus M. Kelley.

—. 1934. Thorstein Veblen and his America. New York, NY: Augustus M. Kelley.

Edgell, Steven. 2002. "Dorfman's Account of Veblen: An Evaluation of a Problematic Intellectual Legacy.” Paper presented at the $4^{\text {th }}$ Conference of the International Thorstein Veblen Association, May 12, 2002 (unpublished).

—. 2001. Veblen in Perspective: His Life and Thought. Armonk: M.E. Sharpe.

Fitch, Robert. 1996. The Assassination of New York. New York: Verso.

Hodgson, Geoffrey. 2004. The Evolution of Institutional Economics. London: Routledge.

Hudson, Michael. 1975. Economics and Technology in 19th Century American Thought: The Neglected American Economists. New York: Garland Press.

—. 2010. America's Protectionist Takeoff: 1815-1914. ISLET.

—. 2011. "Simon Patten on Public Infrastructure and Economic Rent Capture.” American Journal of Economics and Sociology 70(4): 873-903.

Kahn, Herman. 1979. “The Expert and Educated Incapacity.” In World Economic Development: 1979 and Beyond. Boulder: Westview Press. 
Langlois, Richard N. 1986. Economics as a Process: Essays in the New Institutional Economics. Cambridge [Cambridgeshire]: Cambridge University Press.

List, Friedrich. 1847. Outlines of American Political Economy. Philadelphia, PA.

Liu, Henry C. K. 2011. "The Rise and Decline of Institutional Economics.” Asia Times Online, April 7. Available at http://henryckliu.com/page246.html.

Mitchell, Wesley Clair. 1967. Types of Economic Theory. New York: A. M. Kelley.

Myers, Gustavus. 1907. History of the Great American Fortunes. Chicago: C.H. Kerr \& Co.

Norris, Frank. 1901. The Octopus; A Story of California. New York: Doubleday, Page \& Co.

Öncü, Ahmet. 2012. "Formation of an Anti-Capitalist Engineer Identity and its Evolution in Turkey: A Veblenian Interpretation.” Remarks at the 2012 Symposium, Veblen, Capitalism and Possibilities for a Rational Economic Order, Istanbul: July 6-7.

Patten, Simon. 1891. “Another View of the Ethics of Land Tenure.” International Journal of Ethics 1(3): 354-370.

— 1899. The Development of English Thought. New York: Macmillan's.

—. 1902. The Theory of Prosperity. New York, NY.

—_. (1912) 1924. “The Reconstruction of Economic Theory.” In Rexford G. Tugwell (ed.), Essays in Economic Theory. New York: Alfred A. Knopf.

Veblen, Thorstein. (1904) 1965. The Theory of Business Enterprise. 1904. New York: A.M. Kelley, bookseller.

— (1906) 1919. The Place of Science in Modern Civilisation: And Other Essays. New York: B.W. Huebsch.

— 1921. The Engineers and the Price System. New York: Viking Press. 1923. Absentee Ownership and Business Enterprise in Recent Times. New York, NY: B.W. Huebsch, Inc. 